\title{
WEBSIG UNTUK EFISIENSI INVENTARIS PENDAPATAN DAERAH SEKTOR PAJAK BUMI DAN BANGUNAN \\ (STUDI KASUS DESA BENER, KECAMATAN SARADAN, KABUPATEN MADIUN)
}

\author{
Dimas Aprian Nugroho' ${ }^{1}$, Hepi Hapsari Handayani² \\ ${ }^{1,2}$ Departemen Teknik Geomatika, FTSPK-ITS, Kampus ITS Sukolilo, Surabaya, 60111, Indonesia \\ e-mail: ${ }^{2}$ hapsari@geodesy.its.ac.id
}

\begin{abstract}
Abstrak
Pajak Bumi dan Bangunan (PBB) merupakan salah satu pajak daerah yang penting bagi daerah. Kontribusi PBB terhadap besarnya pembiayaan daerah cukup tinggi. Maka diperlukan adanya efisiensi dalam proses pengelolaannya. Hal ini perlu dimulai dari lingkup kecil seperti Desa. Dengan berkembangnya teknologi Sistem Informasi Geografis (SIG), tentu dapat dimanfaatkan untuk mengefisiensikan pengelolaan PBB dengan menggunakan teknologi WebSIG. Penelitian ini menggunakan data PBB dari buku Daftar Himpunan Ketetapan Pajak (DHKP) Desa Bener Tahun 2019, Peta bidang tanah versi Kantor Badan Pertanahan Nasional (BPN) Kabupaten Madiun, dan versi Kantor Desa Bener. Data buku DHKP diolah menjadi tabel basis data pada WebSIG. Data bidang tanah pada kedua peta bidang tanah disatukan menjadi data spasial WebSIG. Bidang tanah pada WebSIG berjumlah 1634 bidang. Dari 1634 bidang, 1323 sudah memiliki informasi PBB yang lengkap, 95 belum memiliki kejelasan NOP, dan 216 lainnya belum teridentifikasi. Dari hasil pengujian WebSIG yang dihasilkan dapat meningkatkan efisiensi dalam pencarian data informasi objek PBB. Data posisi objek PBB diperoleh dengan lebih mudah, tanpa menggunakan peta cetak berukuran besar dan memakan banyak tempat. Dengan adanya WebSIG ini informasi objek PBB dapat diakses dimana saja dan kapan saja melalui komputer maupun smartphone, selama terdapat koneksi internet sehingga dapat mempermudah dalam proses pengelolaan PBB.
\end{abstract}

Kata Kunci: Peta Desa, Pembangunan Desa, Data Spasial, Penyajian Peta

\begin{abstract}
Land and Building Tax (PBB) is one of the important local taxes for the region. PBB contribution to the amount of regional budget is quite high. Therefore, efficiency is needed in the management process. This needs to start from small publications such as the Village. By developing Geographic Information System (GIS) technology, of course it can be used to streamline the management of the PBB by using WebGIS technology. This study uses PBB data from the 2019 Bener Village Tax Assessment Book (DHKP) List, Maps of Madiun District from Office of National Land Agency (BPN), and Maps of Madiun District from the Bener Village Office. DHKP book data is processed into tables based on data on WebGIS. Land plot data in the field map is integrated into WebGIS spatial data. There are 1634 fields plots of land on WebSIGergian 1634. From those 1634 fields, 1323 already have complete PBB information, 95 do not yet have NOP clarity, and 216 others have not been identified. The result show improvement of efficiency in the search for information on PBB object data. The object position data is obtained more easily, without using a large printed map which takes a lot of space. With this WebGIS, information on tourist attractions can be accessed anywhere and anytime through a computer or smartphone, as long as there is an internet connection so that it can facilitate the PBB management process.
\end{abstract}

Keywords: Village Map, Village Development, Spatial Data, Map Presentation 


\section{PENDAHULUAN}

Berdasarkan Peraturan Daerah Kabupaten Madiun No. 12 tahun 2010 tentang pajak daerah, Pajak Bumi dan Bangunan Perdesaan dan Perkotaan merupakan pajak atas bumi dan/atau bangunan yang dimiliki, dikuasai, dan/atau dimanfaatkan oleh individu maupun Badan, terkecuali kawasan perhutanan, pertambangan, dan perkebunan (Bupati 2010). Sesuai dengan Undang-Undang Nomor 28 Tahun 2009 tentang Pajak Daerah dan Retribusi Daerah (PDRD), pengelolaan atas Pajak Bumi dan Bangunan (PBB) Sektor Perdesaan dan Perkotaan (P2) ditangani oleh Kabupaten/Kota (DPR 2009).

Berdasarkan Undang - Undang PDRD pasal 80, tarif PBB-P2 dari masing-masing Kabupaten/Kota dapat ditentukan sendiri dengan ketentuan paling tinggi sebesar $0,3 \%$ dari nilai sebelumnya yang hanya dipatok pada tarif efektif (tunggal) sebesar $0,1 \%$ atau $0,2 \%$. Hal ini menyebabkan munculnya ruang bagi Kabupaten/Kota untuk menaikkan tarif PBB-P2 di wilayahnya secara legal. Dengan adanya pengalihan ini, penerimaan PBB-P2 akan sepenuhnya diterima oleh Pemerintah Kabupaten/Kota sehingga diharapkan mampu meningkatkan Pendapatan Asli Daerah (PAD)nya (Budi 2014). Seperti halnya Di Kabupaten Madiun, dalam pemungutan PBB Pemerintah Kabupaten Madiun bekerja sama dengan pihak desa dan kelurahan dalam hal pemungutan Pajak Bumi dan Bangunan di wilayahnya masing-masing. Untuk itu diperlukan adanya pengelolaan PBB yang efisien agar penerimaan yang didapatkan menjadi lebih maksimal. Namun dalam pelaksanaannya masih dilakukan secara tidak efisien, seperti di Desa Bener, Kecamatan Saradan, Kabupaten Madiun.

$\mathrm{Di}$ kantor Desa Bener kegiatan pengelolaan kegiatan yang berkaitan dengan PBB masih dilakukan secara tidak efisien. Misalnya ketika petugas ingin mencari posisi objek PBB, petugas harus mencocokan data yang ada di Surat Pemberitahuan Pajak Terhutang (SPPT) dengan peta bidang berukuran $\mathrm{AO}$ berjumlah 6 lembar. $\mathrm{Hal}$ ini tentu akan membuat pekerjaan menjadi tidak efektif dan memakan waktu lebih lama. Maka dari itu adanya sebuah sistem informasi objek PBB untuk meningkatkan efisiensi pengelolaan pendapatan daerah sektor PBB.

\section{METODOLOGI PENELITIAN}

\section{Lokasi Penelitian}

Studi kasus penelitian ini berada di Desa Bener, Kecamatan Saradan, Kabupaten Madiun. Secara astronomis Desa Bener terletak pada $7^{\circ} 30^{\prime} 25^{\prime}$ $7^{\circ} 31^{\prime} 29^{\prime \prime}$ LS dan $111^{\circ} 40^{\prime} 25^{\prime \prime}-111^{\circ} 41^{\prime} 20^{\prime \prime}$ BT, dengan luas wilayah sekitar $2,29 \mathrm{~km}^{2}$.

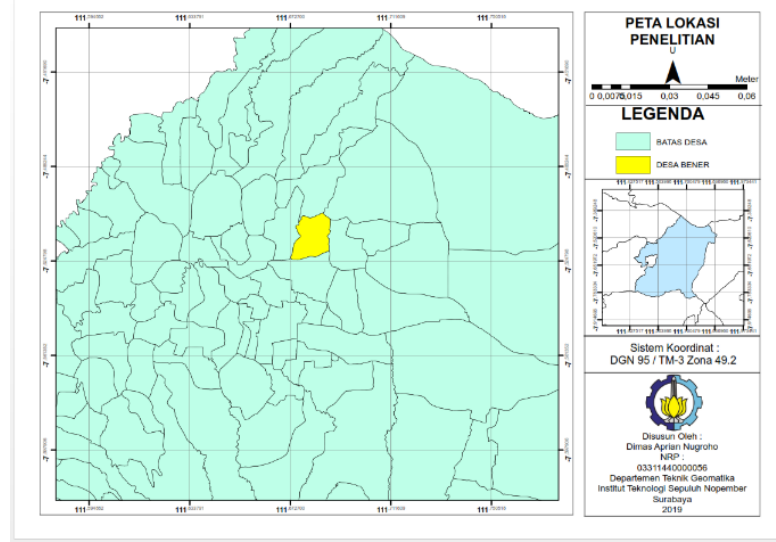

Gambar 1. Peta Lokasi Penelitian

Batas administratif dari Desa Bener dibatasi oleh:

Sebelah Utara

Sebelah Barat

Sebelah Selatan

: Desa Duren

Sebelah Timur

: Desa Kedungmaron

: Desa Sukorejo

: Desa Sumbersari

\section{Data dan Peralatan}

Data yang dipakai pada penelitian kali ini meliputi yaitu:

a. Data Spasial

1) Peta Bidang Tanah Desa Bener yang diperoleh dari Kantor Badan Pertanahan Nasional (BPN) Kabupaten Madiun

2) Peta Bidang Tanah Desa Bener versi cetak yang diperoleh dari Kantor Desa Bener.

b. Data non-spasial berupa salinan buku Daftar Himpunan Ketetapan Pajak (DHKP) Desa Bener Tahun 2019.

Untuk peralatan yang dipakai pada penelitian kali ini meliputi yaitu :

a. Perangkat Keras

1) Laptop

b. Perangkat Lunak

1) Perangkat lunak pengolah kata

2) Perangkat lunak pengolah angka 
3) Perangkat lunak pemrosesan grafis berupa Sistem Informasi Geografis (SIG)

4) QuantumGIS (QGIS) 3.10 .1

5) Sublime Text

\section{Tahapan Pengolahan Data}

Pengolahan data pada penelitian kali ini digambarkan pada diagram alir pada Gambar 2.

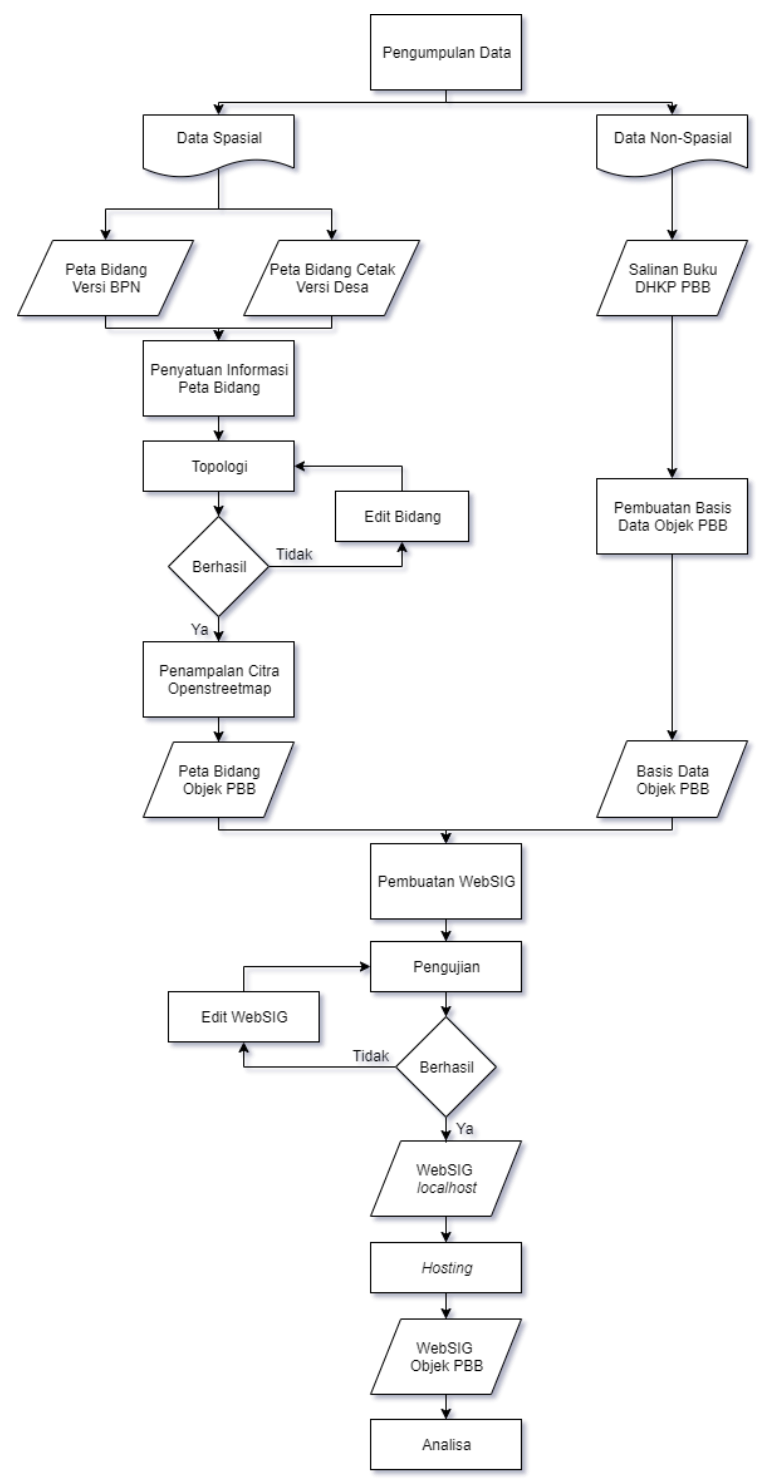

Gambar 2. Diagram Alir Pengolahan Data

\section{HASIL DAN PEMBAHASAN}

\section{Peta Objek PBB}

Peta bidang versi BPN Kabupaten Madiun disamakan informasinya dengan peta bidang tanah versi cetak yang dimiliki oleh Kantor Desa dengan cara digitiasi. Proses ini diperlukan untuk menyamakan jumlah bidang serta memberikan informasi kepemilikan tiap bidang tanah di peta bidang yang didapatkan dari BPN Kabupaten Madiun. Tampilan dari hasil penggabungan ini digambarkan kedalam peta objek PBB pada Gambar 3.

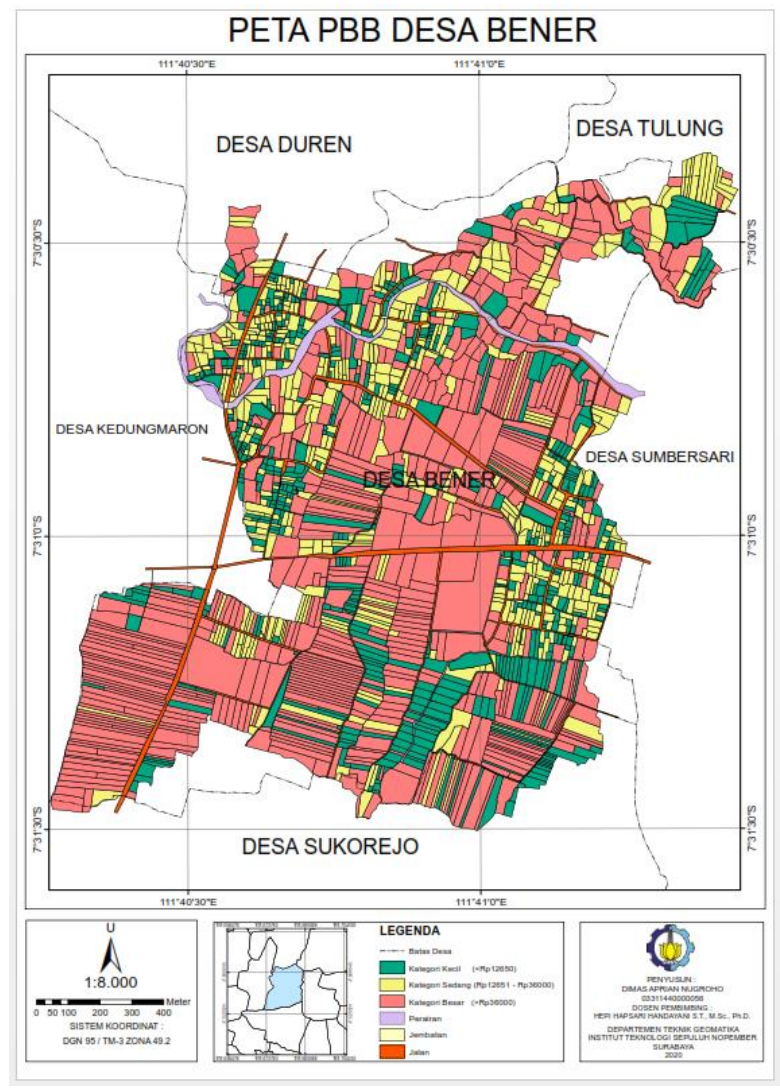

Gambar 3. Peta PBB Desa Bener

Berdasarkan analisa peta objek PBB yang telah dibuat terdapat 262 bidang yang berbeda penggambarannya antara pihak BPN Kabupaten Madiun dengan Kantor Desa. Hal ini terjadi dikarenakan adanya perbedaan informasi jumlah lahan pada peta bidang objek PBB versi Kantor Desa dengan versi BPN Kabupaten Madiun.

Informasi lain yang dapat didapatakan dari peta objek PBB yang dibuat ditunjukkan pada Tabel 1. Berdasarkan Tabel 1. dari total 1640 bidang tanah yang ada di Desa Bener, baru 1317 bidang yang telah memiliki informasi PBB yang lengkap. Sebanyak 216 bidang belum memiliki informasi PBB sama sekali, hal ini disebabkan adanya perbedaan informasi jumlah objek PBB yang didapatkan dari peta bidang versi BPN, peta bidang versi Kantor Desa, dan data dari buku DHKP Desa Bener. 
Tabel 1. Hasil Analisa Peta Objek PBB Hasil Penggabungan Data Spasial

\begin{tabular}{clc}
\hline No & \multicolumn{3}{c}{ Keterangan } & Jumlah \\
\hline 1 & $\begin{array}{l}\text { Jumlah total keseluruhan } \\
\text { bidang }\end{array}$ & 1640 \\
2 & $\begin{array}{l}\text { Jumlah bidang yang belum } \\
\text { jelas informasi kepemilikannya }\end{array}$ & 216 \\
3 & $\begin{array}{l}\text { Jumlah bidang yang belum } \\
\text { lengkap informasi PBBnya }\end{array}$ & 101 \\
\hline
\end{tabular}

Sebanyak 1424 bidang sudah memiliki informasi PBB, akan tetapi ter dapat bidang tanah yang informasinya masih belum jelas. Sebanyak 101 bidang tanah masih belum memiliki Nomor Objek Pajak (NOP) yang jelas tetapi sudah memiliki informasi kepemilikannya. Hal ini dapat terjadi salah satunya dikarenakan adanya proses penggabungan, pemecahan, maupun transaksi lahan yang belum tercatat sehingga terjadi ketidak sesuaian data antara buku DHKP Desa Bener dengan peta Bidang Tanahnya.

\section{Basis Data Objek PBB}

Basis data dibuat menggunakan perangkat lunak pengolah angka. Semua data yang ada di salinan buku DHKP Desa Bener Tahun 2019 dimasukkan kedalam tabel. Kemudian tabel disimpan kedalam file berformat .csv agar bisa diolah kedalam WebSIG yang dibuat. Basis data pada penelitian ini terdiri dari 4 tabel, yaitu tabel lahan, lokasi, pembayaran dan penggunan. Hubungan antar tabel digambarkan pada rancangan basis data yang digambarkan kedalam model konseptual, logikal, serta fisikal berikut:

a. Rancangan Model Konseptual

Model konseptual digambarkan kedalam bentuk diagram Entity Relationship (E-R). Diagram ini berisikan entitas, hubungan entitas, dan atribut dari entitas. Rancangan Model Konseptual digambarkan pada Gambar 4.

Hubungan antar entitas yang ditunjukkan pada gambar 4.4, menggunakan hubungan 1 to 1 dan many (m) to 1 . Hubungan 1 to 1 menunjukkan hubungan antara dua entitas A dan B, dengan elemen dari $A$ hanya berhubungan dengan satu elemen dari B. Contohnya pada hubungan entitas bidang dengan lahan menunjukkan satu bidang hanya memiliki satu informasi lahan. Sedangkan pada hubungan $\mathrm{m}$ to 1 menunjukkan hubungan antara dua entitas A dan B, dengan beberapa elemen dari $A$ dapat berhubungan dengan salah satu elemen dari B. Contohnya pada hubungan antara lahan dan lokasi menunjukkan bahwa lebih dari satu lahan dapat berada di satu lokasi.

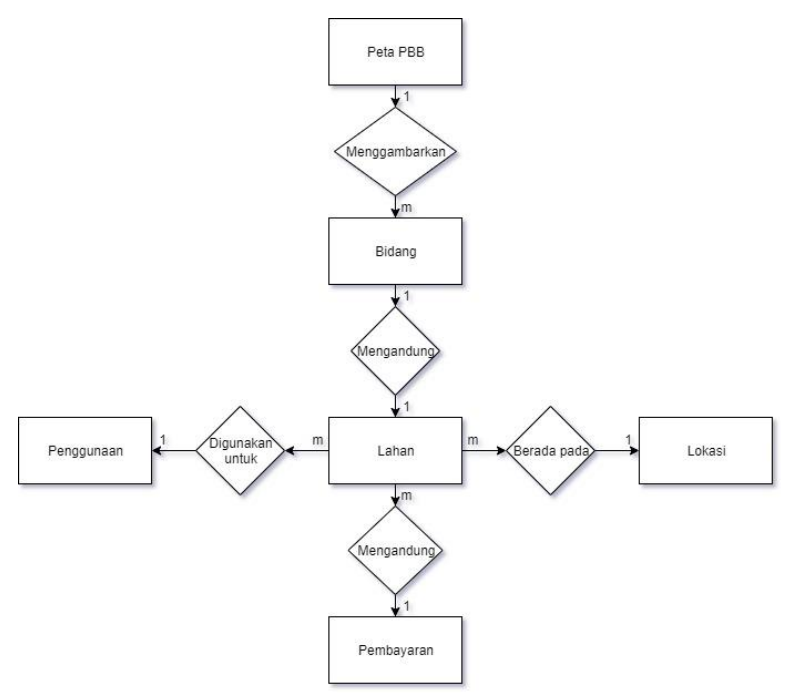

Gambar 4. Rancangan Model Konseptual

b. Rancangan Model Logikal

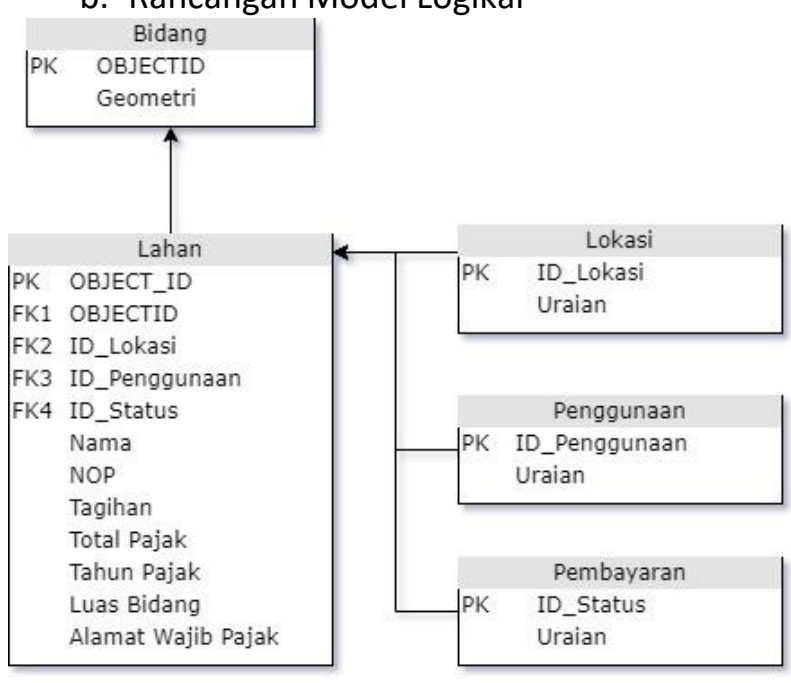

Gambar 5. Rancangan Model Logikal

Model logikal berisikan rangkaian hasil dari perancangan model konseptual. Pada model logikal, proses perancangan basis data mulai dipetakan. Model logikal berisikan rancangan atribut beserta penentuan primary key (PK) dan foreign key (FK) yang digunakan untuk menghubungkan tiap entitasnya. Rancangan model logikal 
pada penelitian ini digambarkan pada Gambar 5.

c. Rancangan Model Fisikal

Model Fisikal berisi implementasi dari perancangan logikal menjadi suatu basis data yang digunakan pada WebSIG yang dibuat pada penelitian Tugas Akhir ini. Rancangan Model Fisikal digambarkan dengan tabel skeleton, seperti pada Tabel 2.

Tabel 2. Tabel Skeleton Rancangan Model Fisikal

\begin{tabular}{|c|c|c|}
\hline No & Entitas & Atribut \\
\hline 1 & Bidang & \#OBJECTID, geometri \\
\hline 2 & Lahan & $\begin{array}{l}\text { \#OBJECT_ID, } \\
\text { OBJECTID, ID_Lokasi, } \\
\text { ID_Penggunaan, } \\
\text { ID_Status, Nama, } \\
\text { NOP, Tagihan, Total } \\
\text { Pajak, Tahun Pajak, } \\
\text { Luas Bidang, Alamat } \\
\text { Wajib Pajak, } \\
\text { Keterangan }\end{array}$ \\
\hline 3 & Lokasi & \#ID_Lokasi, Uraian \\
\hline 4 & Penggunaan & $\begin{array}{l}\text { \#ID_Penggunaan, } \\
\text { Uraian }\end{array}$ \\
\hline 5 & Pembayaran & \#ID_Status, Uraian \\
\hline
\end{tabular}

\section{WebSIG Objek PBB Desa Bener}

Tujuan dibuatnya WebSIG dalam penelitian ini yaitu, untuk menyajikan berbagai informasi data PBB objek pajak yang dapat dimanfaatkan untuk meningkatkan efisiensi dari kegiatan yang berkaitan dengan PBB di Desa Bener. Misalkan, petugas dari Kantor Desa ingin mencari informasi tentang objek PBB beserta posisinya. Petugas tidak perlu lagi harus mencari nama pemilik dan NOP di buku DHKP kemudian mencari lokasinya pada peta cetak ukuran A0 sejumlah 6 lembar. Petugas hanya perlu mengakses WebSIG yang dibuat dan memilih nama pemilik dari objek PBB yang ingin diketahui informasinya, kemudian informasi data dan posisi dari objek PBB tersebut akan muncul pada tampilan WebSIG.

WebSIG Desa Bener yang dibuat pada penelitian ini dapat diakses melalui domain www.pbbbener.id. Saat mengunjungi domain, pengguna akan diarahkan menuju laman login yang ditunjukkan pada gambar 6 .

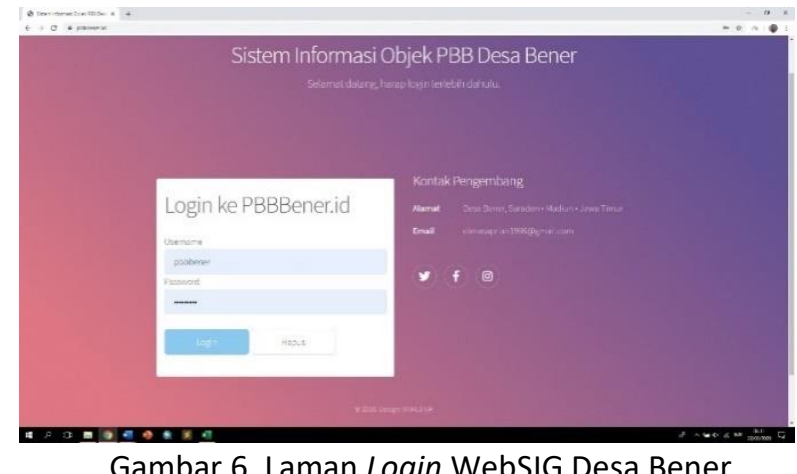

Setelah proses login pengguna akan diarahkan menuju laman utama dari WebSIG Desa Bener. Laman utama ini terdiri dari beberapa konten yaitu laman selamat datang, konten tentang Desa, konten profil desa, konten Pajak Bumi dan Bangunan, konten sistem informasi, dan konten kontak pengembang.

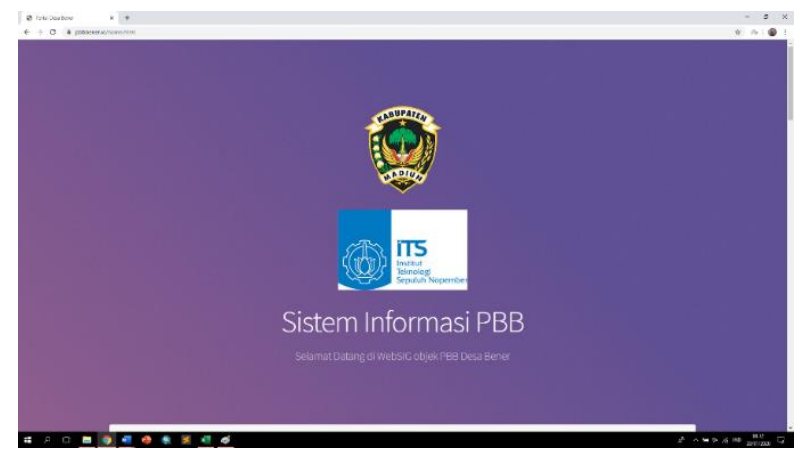

Gambar 7. Laman Selamat Datang WebSIG Desa Bener

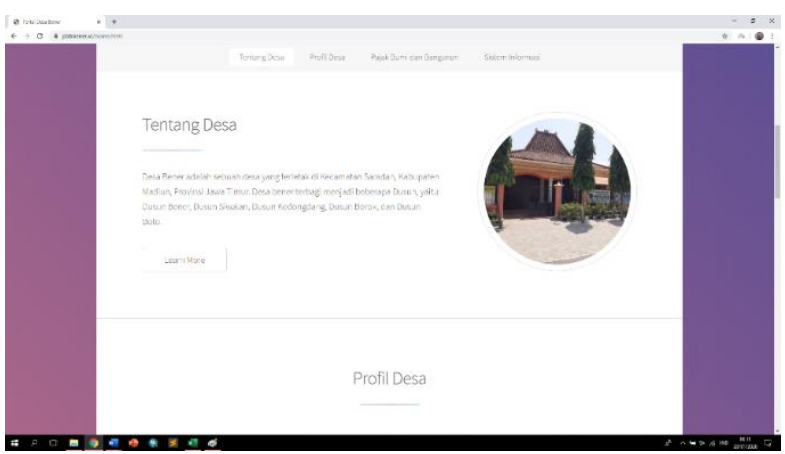

Gambar 8. Konten Tentang Desa WebSIG Desa Bener

Gambar 8 merupakan tampilan dari konten tentang Desa. Konten ini berisikan gambaran umum mengenai Desa Bener. 


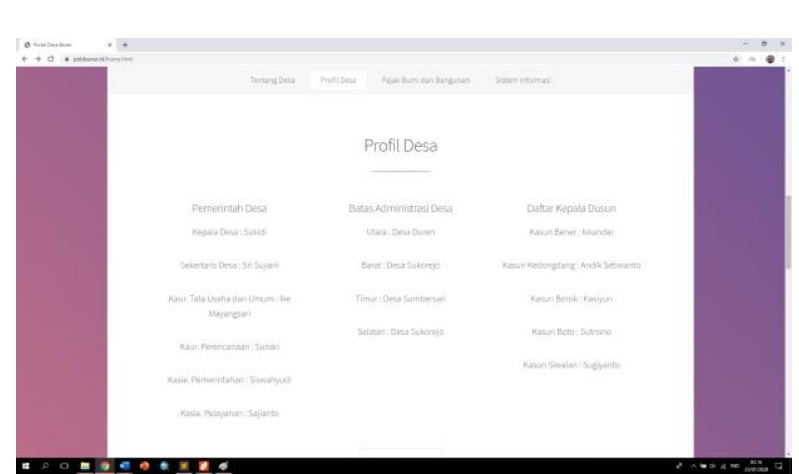

Gambar 9. Konten Profil Desa WebSIG Desa Bener

Gambar 9 merupakan tampilan dari konten profil Desa. Konten ini berisikan struktur pemerintahan Desa, batas administrasi Desa, dan daftar Kepala Dusun wilayah Desa Bener.

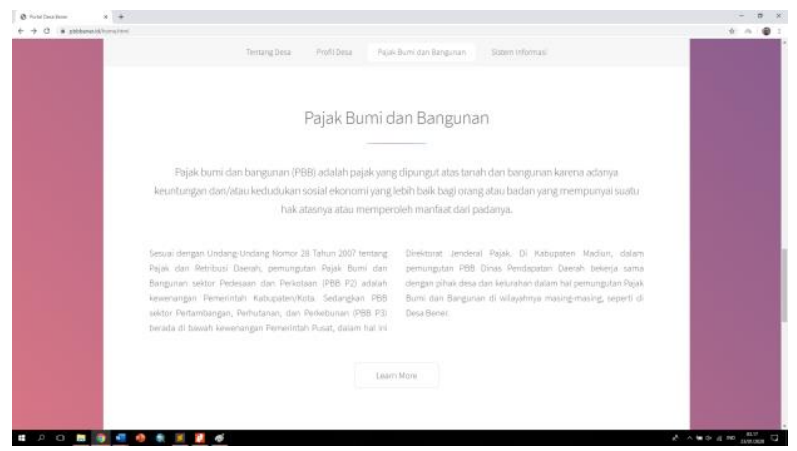

Gambar 10. Konten Pajak Bumi dan Bangunan WebSIG Desa Bener

Gambar 10 merupakan tampilan dari konten tentang Pajak Bumi dan Bangunan. Konten ini berisikan ringkasan mengenai PBB.

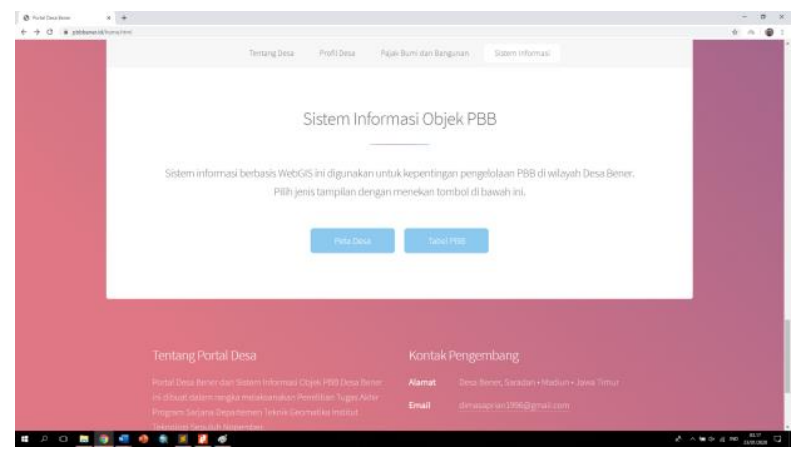

Gambar 11. Konten Sistem Informasi WebSIG Desa Bener

Gambar 11. merupakan tampilan dari konten sistem informasi. Konten ini berisikan sistem informasi objek PBB yang dibuat. Pada konten sistem informasi, pengguna dapat mengakses data spasial dan non-spasial Objek PBB
Desa Bener. Terdapat 2 menu pilihan, yang pertama Peta Desa yang berisikan peta bidang tanah objek PBB beserta basis data informasi objek PBB.

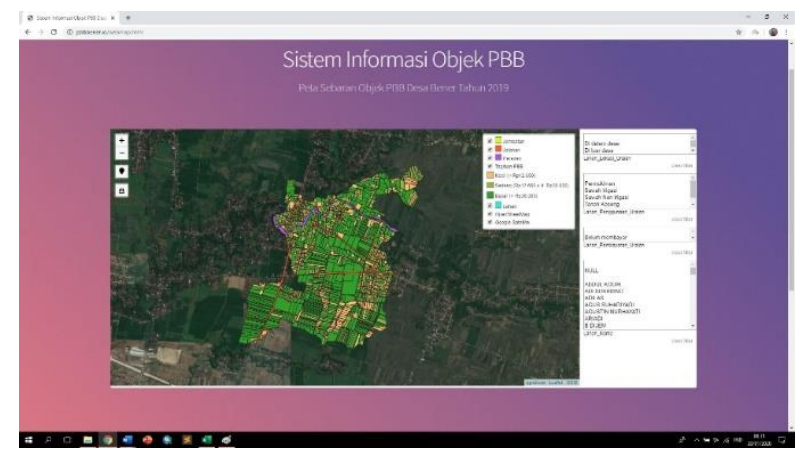

Gambar 12. Menu Peta Desa WebSIG Desa Bener

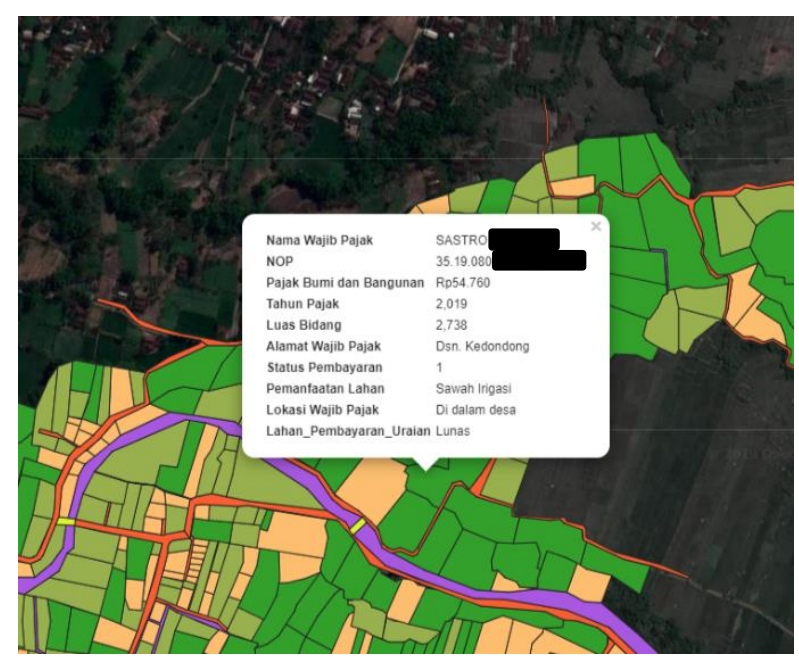

Gambar 13. Penyajian Informasi Objek PBB Pada Peta WebSIG

Pada bagian Peta PBB ini terdapat beberapa fitur - fitur pencarian data infomasi objek PBB beserta posisi bidang tanahnya. Fitur yang pertama yaitu seleksi objek PBB berdasarkan jenis objeknya. Fitur ini berfungsi untuk memilah data yang ditampilkan pada peta WebSIG.

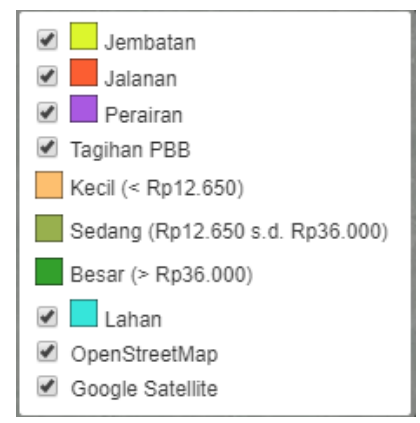

Gambar 13. Tampilan Fitur Seleksi Objek Pada Peta WebSIG Desa Bener 
Fitur selanjutnya yaitu fitur pencarian berdasarkan lokasi tempat tinggal sang pemilik lahan. Lokasi ini dibedakan menjadi 3 kategori yaitu di dalam Desa, di luar Desa, dan di luar Kabupaten.

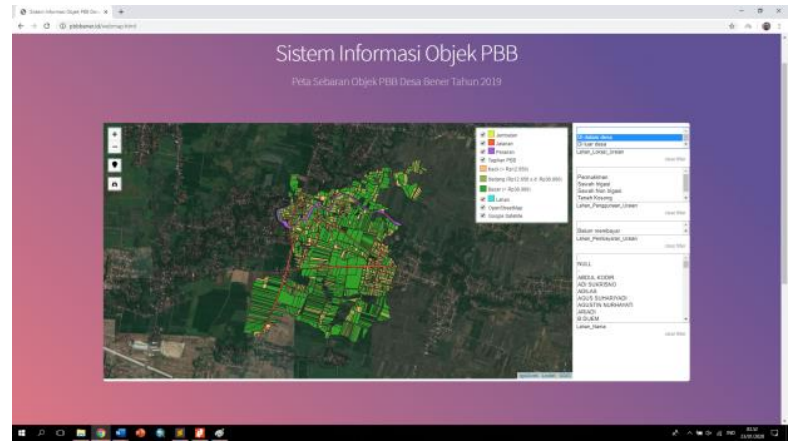

Gambar 14. Contoh Tampilan Fitur Pencarian Berdasarkan Lokasi Pada Peta WebSIG Desa Bener

Selanjutnya terdapat fitur pencarian berdasarkan penggunaan Lahan. Fitur ini berfungsi untuk memilih informasi posisi objek PBB yang ditampilkan pada peta berdasarkan penggunaan lahan objek PBB. Terdapat 5 kategori dalam fitur ini yaitu kategori pemukiman, sawah irigasi, sawah non irigasi, lahan kosong, dan tegalan.

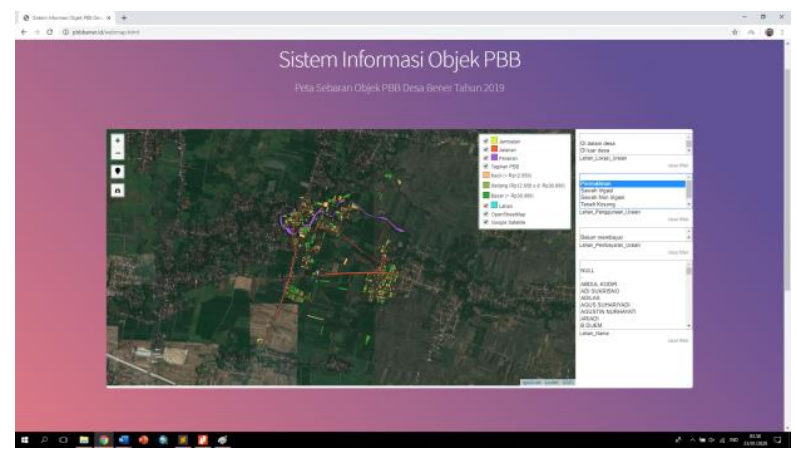

Gambar 15. Contoh Tampilan Fitur Pencarian Berdasarkan Penggunaan Lahan WebSIG Desa Bener

Selanjutnya fitur pencarian berdasarkan status pembayaran. fitur ini berfungsi untuk memilih informasi posisi objek PBB yang ditampilkan pada WebSIG berdasarkan status pembayaran tagihan PBB. Kategori ini dibedakan menjadi 2 yaitu kategori lunas dan belum bayar.

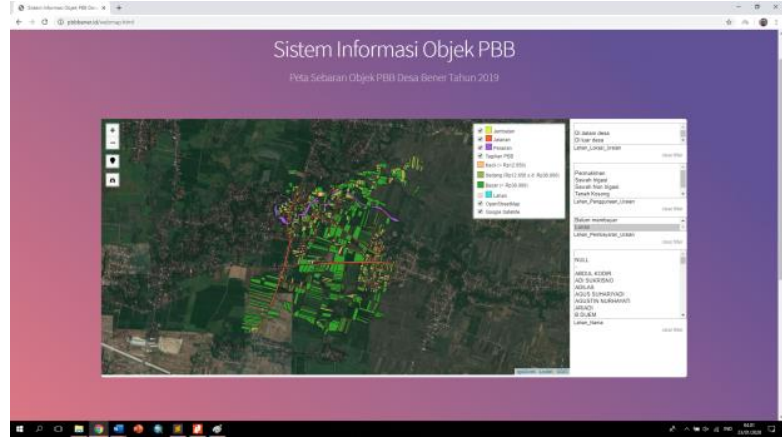

Gambar 16. Contoh Tampilan Fitur Pencarian Berdasarkan Status Pembayaran WebSIG Desa Bener

Fitur yang terakhir yaitu fitur pencarian berdasarkan nama pemilik lahan. Fitur ini berfungsi untuk memilih informasi posisi objek PBB yang ditampilkan pada WebSIG berdasarkan nama pemilik lahan objek PBB. Fitur pencarian ini memiliki peranan yang penting, dikarena satu orang bisa saja memiliki tidak hanya satu lahan, tetapi beberapa lahan. Untuk itu fitur pencarian ini akan sangat membantu dalam mensortir informasi objek PBB mana yang ingin didapatkan dari sang pemilik lahan.

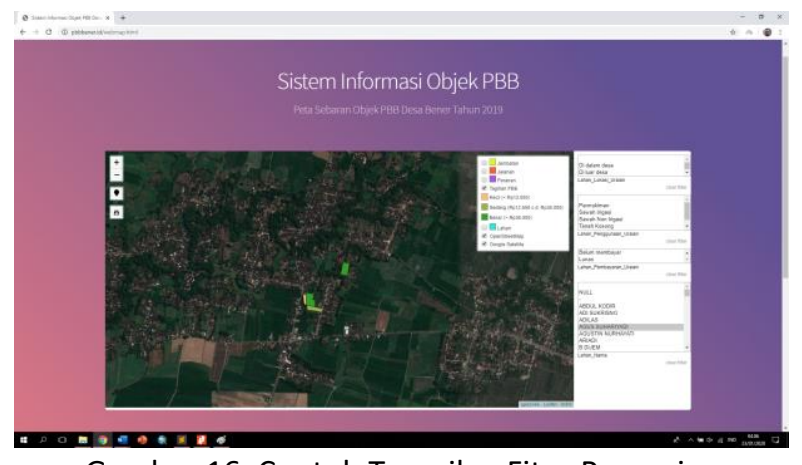

Gambar 16. Contoh Tampilan Fitur Pencarian Berdasarkan Status Pembayaran WebSIG Desa Bener

Menu lainnya yang ada pada konten Sistem informasi yaitu menu tabel PBB. Menu ini berisikan data informasi objek PBB yang dapat diunduh untuk keperluan pengelolaan PBB seperti misalnya untuk proses monitoring pembayaran tagihan PBB. 


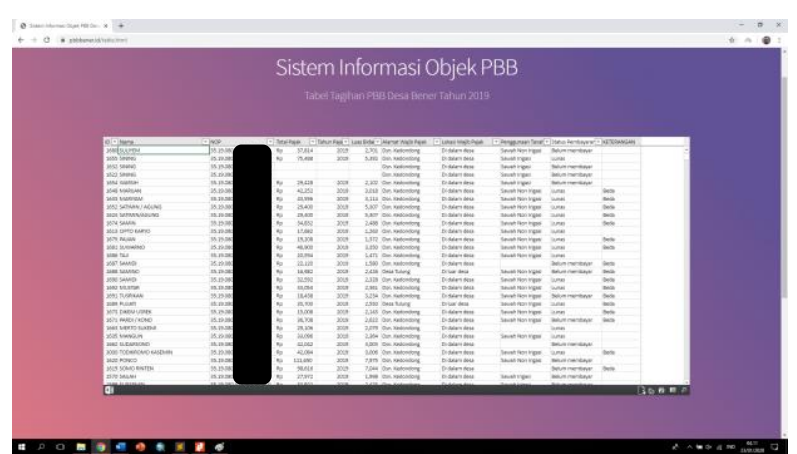

Gambar 12. Menu Tabel PBB WebSIG Desa Bener

Konten terakhir pada WebSIG Objek PBB Desa Bener pada penelitian ini yaitu konten kontak pengembang. Konten ini berisikan informasi kontak yang dapat dihubungi dari sang pengembang WebSIG. Konten ini berfungsi sebagai jembatan bagi pengguna jika ingin bertanya seputar WebSIG objek PBB Desa Bener kepada pengembang. Kontak disini berisikan 3 opsi yaitu kontak melalui facebook, twitter, atau instagram.

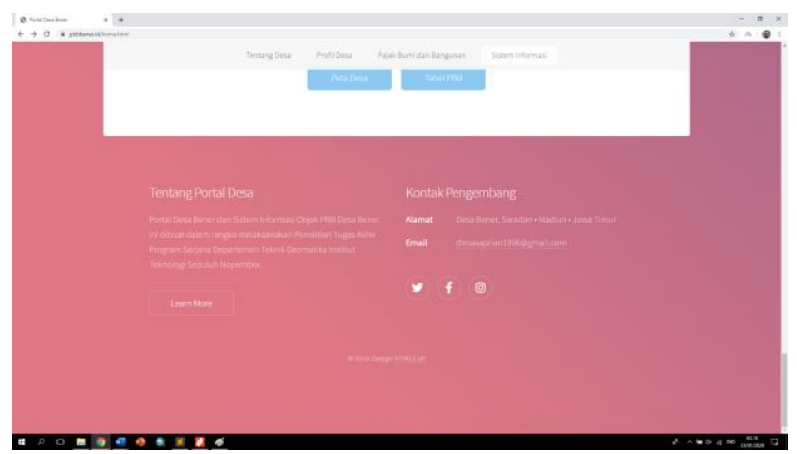

Gambar 12. Konten Kontak Pengembang WebSIG Desa Bener

\section{Pengujian WebSIG Objek PBB Desa Bener}

Tahap ini diperlukan untuk mengetahui tingkat keberhasilan pembuatan sistem informasi PBB. Pengujian dilakukan dengan menggunakan pengujian sistem dan pengujian usability. Pengujian sistem dilakukan dengan pemilihan informasi yang dibutuhkan oleh pengguna, berdasarkan fitur pencarian yang telah disediakan pada WebSIG. Hasil dari pemilihan ini menunjukan status berhasil atau tidaknya fitur pencarian yang berada pada sistem.

Pengujian sistem digunakan untuk mengetahui ketepatan visualisasi hasil pencarian data informasi dalam bentuk spasial. Untuk pengujian usability dilakukan mengacu pada penelitian Amarrohman (2017) dengan cara memberikan kuesioner kepada 7 orang pihak Kantor Desa yang menangani bidang PBB dan skoring menggunakan metode likert. Hasil pengujian sistem ditunjukkan pada Tabel 3.

Tabel 3. Hasil pengujian sistem

\begin{tabular}{cll}
\hline No & \multicolumn{1}{c}{ Fitur Yang Diuji } & Status \\
\hline $\mathbf{1}$ & Seleksi Objek Pada Peta & \\
& Menampilkan objek jembatan & Berhasil \\
& menampilkan objek jalan & Berhasil \\
& menampilkan objek perairan & Berhasil \\
& Menampilkan Bidang Tanah & Berhasil \\
$\mathbf{2}$ & $\begin{array}{l}\text { Pencarian berdasarkan kediaman } \\
\text { pemilik lahan }\end{array}$ &
\end{tabular}

Menampilkan bidang tanah yang pemiliknya di dalam Desa

Berhasil

Menampilkan bidang tanah yang pemiliknya di luar Desa

Berhasil

Menampilkan bidang tanah yang

Berhasil pemiliknya di luar Kabupaten

3

\section{Pencarian berdasarkan penggunaan lahan}

Menampilkan bidang tanah untuk pemukiman

Berhasil

Menampilkan bidang tanah untuk sawah irigasi

Menampilkan bidang tanah untuk sawah non irigasi

Menampilkan bidang tanah untuk lahan kosong

Menampilkan bidang tanah untuk tegalan

Berhasil

Berhasil

Berhasil

Berhasil

4

\section{Pencarian berdasarkan status pembayaran}

Menampilkan bidang tanah dengan Berhasil status pembayaran Lunas

Menampilkan bidang tanah dengan status pembayaran belum Berhasil membayar

5 Pencarian berdasarkan nama

Menampilkan bidang tanah atas nama pemilik lahannya
Berhasil 
Berdasarkan pengujian WebSIG pada tabel 3, semua pengujian fitur berstatus berhasil. Dari 5 fitur pencarian yang telah diuji menghasilkan informasi dan lokasi yang tepat sesuai dengan kebutuhan. Dengan menggunakan persamaan (Sugiono 2012):

$$
P=\frac{f}{N} \times 100 \%
$$

P : persentase hasil pengujian

$\mathrm{f}$ : frekuensi dari setiap jawaban

$\mathrm{N}$ : jumlah skor ideal

100 : bilangan tetap.

Dapat dihitung tingkat keberhasilan pengujian sistem sebesar $100 \%$. Persentase keberhasilan ini menunjukkan bahwa WebSIG yang dibangun telah mampu untuk melakukan pencarian data dengan menghasilkan informasi yang tepat.

Pengujian Usability dilakukan dengan menyebar kuesioner yang berisikan 5 kriteria pengujian kepada responden. Hasil dari pengujian usability ditunjukkan pada Tabel 4 .

Tabel 4. Hasil pengujian usability

\begin{tabular}{cccccc}
\hline & \multicolumn{5}{c}{ Jumlah Responden } \\
\cline { 2 - 6 } Pengujian & $\begin{array}{c}\text { Sangat } \\
\text { Setuju }\end{array}$ & Setuju & Ragu & $\begin{array}{c}\text { Tidak } \\
\text { Setuju }\end{array}$ & $\begin{array}{c}\text { Sangat } \\
\text { Tidak } \\
\text { Setuju }\end{array}$ \\
\hline 1 & 0 & 7 & 0 & 0 & 0 \\
2 & 0 & 7 & 0 & 0 & 0 \\
3 & 0 & 7 & 0 & 0 & 0 \\
4 & 0 & 7 & 0 & 0 & 0 \\
5 & 0 & 7 & 0 & 0 & 0 \\
\hline
\end{tabular}

Berdasarkan hasil dari kuesioner yang ditunjukkan pada tabel 4, ketujuh responden memberikan penilaian "setuju" untuk pengujian 1 sampai dengan pengujian 5. Berdasarkan perhitungan dengan menggunakan persamaan (Sugiono 2012):

$$
\operatorname{Pr}=\frac{S C}{S I} \times 100 \%
$$

Keterangan :

Pr : persentase capaian

SC : jumlah skor capaian

SI : jumlah skor ideal
100 : bilangan tetap

Diperoleh hasil persentase capaian sebesar $80 \%$. Berdasarkan kriteria kelayakan yang mengacu pada penelitian Amarrohman (2017), dengan persentase pencapaian $80 \%$ maka WebSIG yang dibangun termasuk kedalam kategori "layak". Dengan hasil ini maka WebSIG yang dibangun telah berjalan dengan baik dan dengan pemanfaatan WebSIG dapat dimanfaatkan untuk meningkatkan efisiensi inventaris pendapatan Daerah sektor PBB.

\section{KESIMPULAN}

Kesimpulan dari penelitian ini adalah:

1. WebSIG yang dibangun dalam penelitian ini, memiliki jumlah bidang tanah sebanyak 1634 bidang. Dari 1634 bidang, 1323 bidang sudah memiliki informasi PBB yang lengkap, 95 bidang belum memiliki NOP yang jelas, dan 216 bidang lainnya belum teridentifikasi informasi PBB-nya.

2. Dari hasil analisa dan pengujian menunjukkan WebSIG yang dibuat dapat membantu mencari data informasi secara tepat dan lebih mudah dibandingkan dengan cara yang lama.

3. Dari hasil pengujian dan analisa menunjukkan WebSIG objek PBB yang dibangun, dapat mempermudah proses monitoring PBB di Desa Bener. Karena WebSIG ini dapat diakses dimana saja dan kapan saja melalui situs www.pbbbener.id pada komputer maupun smartphone, selama terdapat jaringan koneksi internet.

4. WebSIG yang dibangun memiliki beberapa kekurangan seperti, untuk proses update data belum bisa otomatis langung pada WebSIG. Selain itu waktu pemrosesan untuk memuat tampilan data peta dan tabel masih tergolong sedikit lambat.

5. Untuk menambah tingkat efisiensi, kedepannya WebSIG ini dapat dikembangkan lagi dengan menambahkan fitur updating data secara otomatis langsung pada situs web-nya.

\section{DAFTAR PUSTAKA}

Amarrohman, F. J., Levitasari, W., dan Nugraha, A. L. 2017. Kajian Pendahuluan Penggunaan Basis Data 
Spasial Objek Pajak Bumi dan Bangunan Berbasis Open Source. Jurnal Geodesi Undip, Volume 6, Nomor 4, Tahun 2017.

Budi, C. 2014. 1 Januari 2014, Semua Kabupaten/Kota Wajib Kelola PBB. https://www.pajak.go.id/id/1januari-2014-semua-kabupatenkota-wajib-kelolapbb. Diakses tanggal 22 Januari 2020.

Bupati. 2010. Peraturan Daerah Kabupaten Madiun Nomor 12 Tahun 2010 Tentang Pajak Daerah Kabupaten Madiun.

DPR dan Presiden. 2009. Undang-Undang Nomor 28 Tahun 2009 tentang Pajak Daerah dan Retribusi Daerah (PDRD). Indonesia.

Sugiono. 2012. "Metodologi Penelitian Pendidikan Pendekatan Kuantitatif, Kualitatif dan R \& D". Bandung: Alfabeta. 